\title{
Interpersonal Relationships in the Primary Classroom: An Analysis of Social and Affective Outcomes
}

\author{
Alison Kington ${ }^{*}$ \\ Institute of Education, University of Worcester, UK. \\ *Corresponding author (E-mail: a.kington@worc.ac.uk)
}

\begin{abstract}
Recent research regarding the quality of relationships in primary classrooms has focused largely on the enhancement and development of cognitive skills. The study reported here focused on a range of social and affective outcomes with the intention of broadening our understanding of the classroom as an interactive system, from the child's perspective. This paper provides empirical evidence on children's perceptions at Key Stage 2 (pupil age 7-11 years) of their relationships with teachers, other adults and children. Data were collected via an attitudinal questionnaire survey in nine primary schools in England. Results indicate that, in addition to the development of social skills, children also valued academic confidence, learning and the involvement of their parents in homework, and that these were associated with the interactions and routines established within the primary classroom settings. Some variations in terms of pupil age, teacher career phase, and the socio-economic context of the school were identified; however, the importance of the relationship between pupil and teacher remained consistent across schools.
\end{abstract}

Keywords - Classroom Relationships, Primary Schools, Pupil Outcomes, Career Phase, Socio-Economic Context

\section{Introduction}

As children progress through early to middle childhood, the amount of time they spend outside the family home engaged in a range of formal and informal activities increases. Formal schooling, which in the UK usually commences at the beginning of the academic year that the child turns five years of age, is one of the entities that occupy a large proportion of children's out-of-home time. Research has recognized that the educational system has one of the most sustained contacts with children and has recognized the importance of understanding the impact of schools on children (Wang, Haertel, \& Walberg, 1997; Werner 2000). Educational research documents our understandings of how school impacts on cognitive, social, behavioral and moral development of the child. Further to this, LaGrange (2004) argues that in the lives of disadvantaged children schools are an important change agent.

Teachers are acknowledged as adults whose relationships with children contribute to the social, emotional, and cognitive development of those children (Birch \& Ladd, 1998; Hamre \& Pianta, 2001; Kington 2005). The relationship that a child has with his or her teacher in the primary phase of schooling is associated with a range of child outcomes, including children's competent behaviour in relationships with peers, as well as their relationships with future teachers (Birch
\& Ladd, 1998; Howes \& Hamilton, 1993; Howes, Hamilton, \& Matheson, 1994). Aspects of the teacher-child relationship are also linked to school adjustment and academic achievement (Birch \& Ladd; 1997; Howes et al., 1994; Pianta, Steinberg \& Rollins, 1995). In addition, positive teacher-child relationships can serve as a buffer against risk (Lynch \& Cicchetti, 1992; Mitchell-Copeland, Denham \& DeMulder, 1997; Pianta et al., 1995).

The growing body of literature examining the nature of teacher-child interaction suggests that teacher relationships make a unique contribution to children's social and cognitive development through adolescence (Resnick et al., 1997). Operating as socializing agents, teachers can influence the quality of students' social and intellectual experiences via their abilities to instil values in children such as the motivation to learn (Brophy, 1998; Oldfather \& Dahl, 1994); by providing classroom contexts that stimulate children's motivation and learning (Perry, 1998; Ryan, Gheen, \& Midgley, 1998); by addressing children's need to belong (Connell \& Wellborn, 1991; Wentzel, 1998); by developing a social identity (Alderman, 1999; Wentzel, 1993); and by serving a regulatory function for the development of emotional, behavioural, and academic skills (Birch \& Ladd, 1997; Pianta, 1997, 1999).

There have been a number of other studies regarding elements of classroom activity which are thought to have an impact upon teacher-pupil relationships, such as the creation 
of productive classroom environments (Hook \& Vass, 2000), the role of authority in the classroom (Robertson, 1996), and how pupils interact with one another in the classroom, both academically (e.g. Kutnick \& Kington, 2005) and socially (Hartup, 1998). Findings such as these indicate that positive early teacher-child relationships may help place children on a trajectory towards higher levels of school adjustment and competence, whereas negative early relationships with teachers forecast a less promising trajectory for children (Kington, 2005).

A further strand of research is concerned with the importance of relationships between students and teachers in shaping the quality of students' motivation and classroom learning experiences. Several reviews of the literature have examined the importance of teachers' instructional practices (Wigfield, Eccles, \& Rodriguez, 1998) as well as the affective and intellectual contexts of classroom learning (Turner \& Meyer, 2000; Osterman, 2000). Additionally, reviews have examined the role students may play in shaping the social context of learning through their beliefs, judgments, goals, and attempts to regulate social behaviour (Patrick, 1997; Pianta, 1999).

The importance of pupil voice in studying interpersonal relationships is increasingly recognised as a key source of evidence on social and/affective outcomes (Christensen \& James, 2008; Flutter \& Rudduck, 2004; Morgan, 2011). Although some global information on these is available via Ofsted reports and government data relating to pupil attendance and exclusion, more detailed evidence was sought through a researcher-administered questionnaire survey to primary school pupils in Years 3 (aged 7-8 years) and 6 (aged 10-11 years). This paper provides an overview of the results of statistical analyses carried out on pupil survey data, collected in 9 case study schools. The key questions that these analyses allowed the study to address include:

- Which sets of survey questions cluster together to form meaningful dimensions (factors)?

- What is the relationship between school factors scores for different factors?

- What is the relationship between factor scores and i) year group, ii) school FSM, and/or iii) teacher career phase?

In responding to these questions, the importance of the research in relation to understanding pupils' perceptions of interpersonal classroom relationships, as well as the impact of these relationships in other areas of schooling, is identified.

\section{Methods}

\subsection{Sample}

The study was conducted between 2009 and 2012 and was based on the distribution of 940 questionnaires to a purposive sample of pupils in nine primary schools in England. The schools were selected on the basis of criteria regarding pupil and teacher population and socio-economic features (such as pupil's eligibility for free school meals). More specifically, the schools were divided into four categories based on their socio-economic characteristics (FSM 1-4 ${ }^{\mathbf{1}}$ ). Of the nine schools, six were in FSM group 3 (21-35\%) or 4 (36\% and above), and three were in FSM 1 (0-8\%) or 2 (9-20\%).

\subsection{Procedures}

For the purposes of this project a pupil questionnaire was developed which could be administered to both Year 3 and Year 6 pupils. The foci of the questions were informed by an initial review of literature and reviews of previous pupil survey instruments (for example, Day, Sammons, Stobart, Kington \& Gu, 2007; Kington, Sammons, Day \& Regan, 2011), and was designed to provide:

- examples of social and affective outcomes of pupils' classroom relationships;

- evidence of the relationships between teacher and pupil in relation to classroom climate;

- evidence of the relationships between other adults, other pupils, classroom conditions; and,

- evidence of pupil engagement and identification with school.

The questionnaire contained 107 closed-ended questions with pre-coded responses under seven main areas:

- $\quad$ you and your teacher (e.g. most of my teachers make me feel comfortable in class; my teacher is easy to talk to; I get along with my teacher)

- $\quad$ your teacher (e.g. My teacher is easy to talk to; I like my teacher)

- $\quad$ your teacher and work (e.g. My teacher is pleased when we work hard; my teacher helps me with my work when I ask; my teacher makes lessons interesting)

- $\quad$ other adults in the classroom (e.g. the adults in the classroom show respect for the pupils; I can discuss my work with other adults in the classroom)

- $\quad$ pupil participation (e.g. my teacher listens to what pupils say about their lessons; pupils' opinions are listened to when decisions are made)

- $\quad$ you and other pupils (e.g. I get on with most of the other pupils in my class; most pupils in my class behave well)

- $\quad$ home-school relationships (e.g. my parents think trying hard is important; my parents are interested in how well I do at school; my teacher checks that my parents have seen my homework diary).

In addition, each questionnaire included two open-ended questions. Questionnaires were administered to approximately 30 pupils (although this varied slightly) in each of the participating classes for the first time in spring 2010, and to different pupils in the same year groups one year later. This gave a total of 500 Year 3 and 440 Year 6 pupils in both rounds of data collection.

\footnotetext{
${ }^{1}$ FSM groups are based on the percentage of pupil eligibility for free school meals: FSM $1=0-8 \%$, FSM $2=9-20 \%$, FSM $3=21-35 \%$, FSM $4=$ $36 \%$ and above.
} 
Table 2.1. Number of Year 3 and Year 6 Pupils Involved in the Questionnaire Survey (in 9 Case Study Schools).

\begin{tabular}{|l|l|l|l|l|}
\hline & \multicolumn{2}{|c|}{ Round 1 } & \multicolumn{2}{c|}{ Round 2 } \\
\hline & No. of pupils & \% of pupils & No. of pupils & \% of pupils \\
\hline Year 3 & 276 & 52 & 224 & 54 \\
\hline Year 6 & 252 & 48 & 188 & 46 \\
\hline TOTAL & $\mathbf{5 2 8}$ & $\mathbf{1 0 0}$ & $\mathbf{4 1 2}$ & $\mathbf{1 0 0}$ \\
\hline
\end{tabular}

Table 2.1 provides a summary of the number of pupils that completed the questionnaires. The questionnaire survey was administered to all pupils in the relevant year groups. However, due to the different class sizes in each of the 9 participating schools, the number of pupils who participated in the survey varied from school to school in both round 1 and round 2. In round 1 numbers of pupils per class ranged from 16 to 39 for Year 3 classes and 19 to 32 for Year 6 classes. Of the round 1 Year 3 responses, just over half (53\%) were from boys and $47 \%$ were given by girls. Of the Year 6 responses, just over half (52\%) were from girls and $48 \%$ were given by boys.

In round 2 (one year later), the numbers ranged from 16 to 32 for Year 3 classes and 12 to 29 for Year 6 classes. Of the round 2 Year 3 responses, just over half (51\%) were from girls and $49 \%$ were given by boys. Of the Year 6 responses, just over half (57\%) were from boys and $43 \%$ were given by girls.

A statistical coding of questions and responses followed the collection of questionnaires. Data elaboration and statistical analysis was performed using SPSS (version 15) and factor analysis was employed to reduce the data from each questionnaire into a number of robust and meaningful underlying dimensions, or factors. In order to investigate whether individual questionnaire items could be drawn together to form underlying factors, principal components analyses (PCA) with Varimax rotation extraction method were run on the data from each of the two year groups.

Prior to performing PCA on each section of the survey, the suitability of data for factor analysis was assessed. In each case, inspection of the correlation matrix revealed the presence of many coefficients of 0.3 and above. The Kaiser-Meyer-Olkin measure for sampling adequacy as an indicator of comparison in the observed values of correlation coefficients to the partial correlation coefficients exceeded the recommended value of 0.7 (Kaiser, 1974) in all cases which implied factor analysis of variables was acceptable as a technique for analysing the data. In addition, Bartlett's Test of Sphericity (Bartlett, 1954) reached statistical significance, supporting the factorability of the correlation matrices.

Having established the number of factors for each scale, a reliability test (Cronbach alpha) was carried out in order to show the level of internal consistency of each factor (or subscale), as well as for the overall scale. Finally, unweighted factor scores were created for each pupil by calculating a mean value (or composite variable) from each item in the factor (SPSS 'Transform / Compute' function). These pupil factor scores were used to generate mean scores for each factor, then each of the common scales, at school level.

\section{Results}

Overall, the pupil responses suggested that interpersonal relationships in these primary classrooms were generally positive 2, that the relationships with the teacher and other pupils were key, that parents had an important part to play, and that the experience of school depends on a number of factors and their interrelationship. Table 3.1 shows the highest and lowest ranked questionnaire items at the Year 3 and Year 6 class levels. Broadly, the results suggest that - at the extremes Year 3 pupils are most positive about spending time with their teacher and least positive about 'my teacher always makes lessons interesting' in round 1 . In round 2, responses are most positive about parents' involvement in work and least positive about finding work too easy.

Year 6 pupils are most positive about making friends and least positive about their parents' involvement in the school in round 1. Again, they are most positive about making friends in round 2 and least positive about good pupil behaviour. However, it is important to note that the spread of responses varies across all items with standard deviations ranging from 0.43 to 0.90 (Year 3) and from 0.50 to 0.80 (Year 6). In other words, there is much more consensus on some items than on others.

In addition to examining the responses of the typical pupil (i.e. mean scores) and the spread of responses for each item (i.e. standard deviations), data reduction techniques were also used to combine results from different questionnaire items. By using this approach, the variation across schools in terms of a reduced and more manageable set of pupil attitude measures could be investigated. Across both Year 3 and Year 6 classes this gave a set of common factors ${ }^{3}$.

\footnotetext{
${ }^{2}$ Year 3 pupils: mean score $=2.40, \mathrm{SD}=0.53$. Year 6 pupils: mean score $2.10, \mathrm{SD}=0.58$. Caution must be exercised in interpreting the distribution of the factor scores, as they generally show a large positive skew due to participants tending to respond with positive ratings, as is the case in many attitude surveys.

${ }^{3}$ A Cronbach alpha score of 0.65 was used as a 'cut-off' point which indicates a moderate level of internal consistency for the scale.
} 
Table 3.1. Highest and Lowest Ranked Questionnaire Items - Round 1 \& Round 2.

\begin{tabular}{|c|c|c|c|c|}
\hline & & & Mean score & Standard deviation \\
\hline Year 3 & Round 1 & Round 2 & & \\
\hline Most positive item & $\begin{array}{l}\text { My teacher is easy to talk to } \\
\text { and spends time just talking } \\
\text { with me }\end{array}$ & $\begin{array}{l}\text { My parents think trying hard } \\
\text { is important }\end{array}$ & $\begin{array}{l}\mathrm{R}^{4} 1-1.53 \\
\mathrm{R} 2-1.20\end{array}$ & $\begin{array}{l}\mathrm{R} 1-0.61 \\
\mathrm{R} 2-0.43\end{array}$ \\
\hline Least positive item & $\begin{array}{l}\text { My teacher always makes } \\
\text { lessons interesting }\end{array}$ & $\begin{array}{l}\text { I often find the work too easy } \\
\text { in class }\end{array}$ & $\begin{array}{l}\mathrm{R} 1-3.46 \\
\mathrm{R} 2-2.61\end{array}$ & $\begin{array}{l}\mathrm{R} 1-0.81 \\
\mathrm{R} 2-0.90\end{array}$ \\
\hline \multicolumn{5}{|l|}{ Year 6} \\
\hline Most positive item & $\begin{array}{l}\text { I have made many friends in } \\
\text { my school }\end{array}$ & $\begin{array}{l}\text { I have made many friends in } \\
\text { my school }\end{array}$ & $\begin{array}{l}\mathrm{R} 1-1.31 \\
\mathrm{R} 2-1.36\end{array}$ & $\begin{array}{l}\mathrm{R} 1-0.50 \\
\mathrm{R} 2-0.55\end{array}$ \\
\hline Least positive item & $\begin{array}{c}\text { My parents/guardians feel } \\
\text { welcome in school and like to } \\
\text { visit it }\end{array}$ & $\begin{array}{l}\text { Pupils behave well at this } \\
\text { school }\end{array}$ & $\begin{array}{l}\mathrm{R} 1-2.34 \\
\mathrm{R} 2-2.75\end{array}$ & $\begin{array}{l}\mathrm{R} 1-0.80 \\
\mathrm{R} 2-0.76\end{array}$ \\
\hline
\end{tabular}

Table 3.2. Factors within Each Scale (Year 3) - Round 1 \& Round 2.

\begin{tabular}{|c|c|c|c|c|c|c|}
\hline Scale & \multicolumn{6}{|c|}{ Factors within each scale } \\
\hline $\begin{array}{c}\text { You \& your } \\
\text { teacher }\end{array}$ & $\begin{array}{c}\text { Relationship with } \\
\text { teacher } \\
\text { (21.8\% variance) }\end{array}$ & $\begin{array}{c}\text { Enjoyment of } \\
\text { learning } \\
\text { (21.3\% variance) }\end{array}$ & $\begin{array}{l}\text { Positive teacher } \\
\text { support } \\
\text { (4.9\% variance) }\end{array}$ & $\begin{array}{l}\text { Interactions with } \\
\text { teacher } \\
\text { (3.9\% variance) }\end{array}$ & $\begin{array}{l}\text { Overall pupil } \\
\text { security } \\
\text { (3.7\% variance) }\end{array}$ & \\
\hline Your teacher & $\begin{array}{c}\text { Approachability } \\
\text { of teacher } \\
\text { (36.2\% variance) }\end{array}$ & $\begin{array}{c}\begin{array}{c}\text { Enjoyment of } \\
\text { teaching }\end{array} \\
\text { (14.4\% variance) }\end{array}$ & $\begin{array}{c}\text { Teacher expecta- } \\
\text { tions } \\
\text { (4.3\% variance) }\end{array}$ & & & \\
\hline $\begin{array}{c}\text { My teacher \& } \\
\text { work }\end{array}$ & $\begin{array}{c}\text { Role behaviours of } \\
\text { teacher } \\
\text { (35.4\% variance) }\end{array}$ & $\begin{array}{l}\text { Clarity of instruc- } \\
\text { tion } \\
\text { (13.3\% variance) }\end{array}$ & $\begin{array}{c}\text { Learning in school } \\
\text { (6.5\% variance) }\end{array}$ & & & \\
\hline $\begin{array}{c}\text { Other adults } \\
\text { in the class- } \\
\text { room }\end{array}$ & $\begin{array}{l}\text { Positive role be- } \\
\text { haviour of other } \\
\text { adults } \\
\text { (28.5\% variance) }\end{array}$ & $\begin{array}{l}\text { Supporting posi- } \\
\text { tive behaviour } \\
\text { (18.6\% variance) }\end{array}$ & $\begin{array}{l}\text { Working ar- } \\
\text { rangements } \\
\text { (3.9\% variance) }\end{array}$ & $\begin{array}{l}\text { Approachability } \\
\text { of other adults } \\
\text { (2.4\% variance) }\end{array}$ & $\begin{array}{c}\text { Interactions } \\
\text { with other } \\
\text { adults } \\
\text { (2.3\% variance) }\end{array}$ & $\begin{array}{c}\text { Relationship } \\
\text { with other } \\
\text { adults } \\
\text { (2.3\% vari- } \\
\text { ance) }\end{array}$ \\
\hline $\begin{array}{c}\text { Pupil partici- } \\
\text { pation }\end{array}$ & $\begin{array}{c}\text { Pupil voice } \\
\text { (31.7\% variance) }\end{array}$ & $\begin{array}{c}\text { Participation in } \\
\text { class activities } \\
\text { (14.3\% variance) }\end{array}$ & $\begin{array}{l}\text { Involvement in } \\
\text { decision-making } \\
\text { (9.0\% variance) }\end{array}$ & & & \\
\hline $\begin{array}{c}\text { You \& other } \\
\text { pupils }\end{array}$ & $\begin{array}{c}\text { Academic confi- } \\
\text { dence pupil } \\
\text { (32.6\% variance) }\end{array}$ & $\begin{array}{c}\text { Interactions with } \\
\text { peers } \\
\text { (11.5\% variance) }\end{array}$ & $\begin{array}{c}\text { Cooperative } \\
\text { working } \\
\text { (8.6\% variance) }\end{array}$ & $\begin{array}{l}\text { Positive behaviour } \\
\text { (5.1\% variance) }\end{array}$ & & \\
\hline $\begin{array}{l}\text { Home-school } \\
\text { relationships } \\
(61.1 \% \text { vari- } \\
\text { ance) }\end{array}$ & $\begin{array}{l}\text { Parental attitude } \\
\text { to pupil learning } \\
\text { (28.8\% variance) }\end{array}$ & $\begin{array}{c}\text { Regular parental } \\
\text { involvement in } \\
\text { pupil homework } \\
\text { (25.4\% variance) }\end{array}$ & $\begin{array}{c}\text { Parental expecta- } \\
\text { tions } \\
\text { (4.2\% variance) }\end{array}$ & $\begin{array}{l}\text { Parental engage- } \\
\text { ment in school } \\
\text { activities } \\
\text { (2.7\% variance) }\end{array}$ & & \\
\hline
\end{tabular}

\footnotetext{
${ }^{4} \mathrm{R}=$ Round

${ }^{5}$ Factors that are italicized are common across both rounds.
} 


\subsection{Identification of common factors}

Factor analysis was used to identify underlying dimensions for each of the sections of the questionnaire that could explain the consistently more positive results in some schools and the consistently less positive results in others. Results of the round 2 analysis were similar to the round 1 results and a number of common factors were found across both Year 3 and Year 6 cohorts, giving confidence in the nature of the underlying dimensions identified.

\subsubsection{Year 3 pupils}

A factor analysis of Year 3 pupils' responses was conducted and an overview of the findings from the analysis is shown in Table 3.2.

You and your teacher $(\mathrm{KMO}=.895$, Bartlett's Test $p<$ $.001)$

From the YOU AND YOUR TEACHER scale, five factors with eigenvalues exceeding 1 were identified (Kaiser, 1974), explaining a total of $55.6 \%$ of the variance (relationship with teacher, enjoyment of learning, positive teacher support, interactions with teacher, overall pupil security). When comparing round 1 and round 2 results, the reliability of the overall YOU AND YOUR TEACHER scale was high for both rounds $(\mathrm{a}=0.88 / \mathrm{a}=0.89)$. Of the five original factors, two of them were seen to be common across both rounds:

- relationship with teacher includes the items most of my teachers treat me the same as other pupils, most of my teachers make me feel comfortable in class, my teacher is easy to talk to, most of my teachers seem to understand me as a person, I get along with most of my teachers $(\mathrm{a}=0.77)$.

- enjoyment of learning includes the items most of what I learn at school is interesting, I think schoolwork is really important, it is really important to me that I learn and develop skills at school, I really enjoy school most of the time, I like most of the lessons ( $\mathrm{a}=0.73$ ).

Your teacher $(\mathrm{KMO}=.846$, Bartlett's Test $p<.001)$

Three factors with eigenvalues exceeding 1 were identified from the YOUR TEACHER scale, explaining a total of $54.9 \%$ of the variance (approachability of teacher, enjoyment of teaching, teacher expectations). The reliability of the overall YOUR TEACHER scale was high in round $1 \mathrm{a}=$ $0.76)$ and round $2(\mathrm{a}=0.74)$. Of the three factors, only one was seen as common across both rounds:

- approachability of teacher includes such items as my teacher is someone I feel I can talk to, my teacher listens to how I feel about the school, I like my teacher (a $=0.82$ ).

My teacher and work $(\mathrm{KMO}=.836$, Bartlett's Test $p<.001)$

Again, three factors with eigenvalues exceeding 1 were identified from the MY TEACHER AND WORK scale, ex- plaining a total of $55.2 \%$ of the variance (role behaviours of teacher, clarity of instruction, learning in school). Reliability of the overall MY TEACHER AND WORK scale was high for both cohorts ( $a=0.80 \& 0.81$ respectively). Of these factors only one was a common factor across both rounds of the survey:

- role behaviours of the teacher includes the items my teacher is always there at the start of lessons, my teacher helps me with my work when I ask, my teacher makes lessons interesting, my teacher is good at explaining if we make mistakes in our work, my teacher tells us when we've done good work $(\mathrm{a}=0.81)$.

Other adults in the classroom $(\mathrm{KMO}=.857$, Bartlett's Test $p<.001)$

A total of six factors with eigenvalues exceeding 1 were identified from the OTHER ADULTS IN THE CLASSROOM scale, explaining a total of $58.0 \%$ of the variance (positive role of other adults, supporting positive behaviour, working arrangements, approachability of other adults, interactions with other adults, relationships with other adults). The reliability of the overall OTHER ADULTS scale was high for round $1(\mathrm{a}=0.82)$ and round $2(\mathrm{a}=0.83)$. Of the original six factors, two were common across both rounds:

- positive role behaviour of other adults includes the items teachers make sure that pupils behave well in lessons, teachers in this school seem to like teaching, teachers in this school show respect for the pupils, teachers in this school treat the pupils fairly, most of my teachers try to help pupils as much as they can ( $\mathrm{a}=$ 0.86).

- supporting positive behaviour includes the items bullying is not tolerated at this school, teachers in this school have the same rules about behaviour $(\mathrm{a}=0.67)$.

Pupil participation $(\mathrm{KMO}=.743$, Bartlett's Test $p<.001)$

Three factors with eigenvalues exceeding 1 were identified from the PUPIL PARTICIPATION scale, explaining a total of $55.0 \%$ of the variance (pupil voice, participation in class activities, involvement in decision-making). The reliability of the overall PUPIL PARTICIPATION scale was moderate $(a=0.73)$, whereas the level of internal consistency for the overall scale was lower with a Cronbach alpha of 0.68. Of the original three factors, one was seen as common across both rounds:

- pupil voice includes the items teachers listen to what pupils say about their lessons, in our school, pupils' opinions are listened to when decisions are made, teachers encourage me to set my own targets/goals at school $(\mathrm{a}=0.72)$.

You and other pupils (KMO $=.842$, Bartlett's Test $p<.001)$

Four factors were identified from the YOU AND OTHER PUPILS scale with eigenvalues exceeding 1 , explaining a total of $57.8 \%$ of the variance (academic confidence in pupil, 
interaction with peers, cooperative working, positive behaviour). The reliability of the overall OTHER PUPILS scale in round 1 was high $(\mathrm{a}=0.78)$ as it was in round $2(\mathrm{a}=0.76)$. One of the four factors was common across both rounds of the survey:

- academic confidence in pupil includes the items I think I will do well in my tests at the end of the year, I am able to understand most of the work we do in class, I feel confident that I will be successful in school, I am learning a lot at school $(\mathrm{a}=0.79)$.

Home-school relationships $(\mathrm{KMO}=.781$, Bartlett's Test $p<$ .001)

Four factors with eigenvalues exceeding 1 were identified from the HOME-SCHOOL RELATIONSHIPS scale. These four components explained a total of $61.1 \%$ of the variance (parental attitude to pupil learning, regular parental involvement in pupil homework, parental expectations, parental engagement in school activities). The reliability of the overall HOME-SCHOOL scale in rounds 1 and 2 was satisfactory (a $=0.68$ and 0.63 respectively) indicating that this scale might not be reliable as an independent unit. Of these factors, two were common across both rounds:

- parental attitude to pupil learning includes the items my parents think I am good at learning, my parents think trying hard is important, my parents are interested in how well I do at school, my parents are interested in the marks I get at school $(\mathrm{a}=0.73)$

- regular parental involvement in pupil homework includes the items I have a school homework folder/diary which my parents must see and sign each week, my teacher checks that my parents have seen my homework diary $(\mathrm{a}=0.86)$.

\subsubsection{Year 6 pupils}

An equivalent factor analysis of Year 6 pupils' responses was conducted and an overview of the findings from the analysis is below in Table 3.3 .

You and your teacher $(\mathrm{KMO}=.876$, Bartlett's Test $p<$ .001)

Five factors with eigenvalues exceeding 1 were identified from the YOU AND YOUR TEACHER scale, explaining a total of $60.8 \%$ of the variance (relationship with teacher, enjoyment of learning, positive teacher support, interaction with teacher, overall pupil security). The reliability for the overall YOU AND YOUR TEACHER scale across both rounds was high $(\mathrm{a}=0.86 / \mathrm{a}=0.87)$. There was one common factor across both rounds:

- relationship with teacher includes the items most of my teachers are interested in me as a person, most of my teachers treat me the same as other pupils, most of my teachers make me feel comfortable in class, most of my teachers seem to understand me $(\mathrm{a}=0.73)$.

Your teacher $(\mathrm{KMO}=.876$, Bartlett's Test $p<.001)$
Seven factors were identified with eigenvalues exceeding 1 from the YOUR TEACHER scale, explaining a total of $61.9 \%$ of the variance (approachability of teacher, enjoyment of teaching, teacher expectations, teacher behaviour, use of praise and reward, teacher feedback and assessment, collegiality). The results for the round 1 analysis had given a high level of consistency for the overall YOUR TEACHER scale $(\mathrm{a}=0.86)$ and this was similar to the round 2 results $(\mathrm{a}=0.87)$. There were no common factors across both rounds.

My teacher and work $(\mathrm{KMO}=.883$, Bartlett's Test $p<.001)$

A total of five factors with eigenvalues exceeding 1 were identified from the MY TEACHER AND WORK scale, explaining a total of $60.8 \%$ of the variance (feelings about work, learning in school, academic confidence, role behaviours of teacher, clarity of instruction). The reliability of the overall MY TEACHER AND WORK scale in round 1 was high $(\mathrm{a}=$ $0.88)$ as it was in round $2(\mathrm{a}=0.91)$. Three of the five factors were common across both rounds of the survey:

- feelings about work includes items such as I am proud of my work, I really enjoy my work most of the time, I like most of the lessons in my school,this school has a good reputation $(\mathrm{a}=0.90)$

- learning in school includes the items I think schoolwork is really important, it is really important to me that I learn and develop my skills at school, all people should get as much education as they can $(\mathrm{a}=0.69)$

- academic confidence in pupil includes the items I am able to understand most of the material covered in my classes, I feel confident that I will be successful in school, I am learning a lot at school, I am satisfied with my marks $(\mathrm{a}=0.76)$.

Other adults in the classroom $(\mathrm{KMO}=.840$, Bartlett's Test $p<.001)$

Only two factors with eigenvalues exceeding 1 were identified in the OTHER ADULTS scale, explaining a total of $55.8 \%$ of the variance (supporting positive behaviour, interactions with other adults). Reliability for round 1 was high (a $=0.83$ ) and slightly lower in round $2(\mathrm{a}=0.76)$. One of the original factors was common across both rounds:

- supporting positive behaviour includes the items bullying is not tolerated at this school, teachers in this school have the same rules about behaviour $(\mathrm{a}=0.77)$.

Pupil participation $(\mathrm{KMO}=.848$, Bartlett's Test $p<.001)$

Again, only two factors were identified from the PUPIL PARTICIPATION scale with eigenvalues exceeding 1, explaining a total of $60.9 \%$ of the variance (participation in class activities, participation in school activities). The reliability of the overall PUPIL PARTICIPATION scale in round 1 was high $(\mathrm{a}=0.79)$. This was also the case in round 2 , with a higher level of internal consistency for the overall scale with a Cronbach alpha of 0.84 . Both factors were common across both rounds: 
- participation in class activities includes the items pupils are often involved in giving feedback to teachers about their teaching, I have helped decide our class rules, in my classes I often have the opportunity to decide what to do for projects and assignments $(\mathrm{a}=$ 0.79).
- participation in school activities items include my parents/guardians come to parents' evenings/events, I often discuss my schoolwork with my parents/guardians $(a=0.87)$.

Table 3.3. Factors within Each Scale (Year 6) - Round 1 \& Round 2.

\begin{tabular}{|c|c|c|c|c|c|c|c|}
\hline \multirow{2}{*}{$\begin{array}{l}\text { Scale } \\
\\
\text { You \& your } \\
\text { teacher }\end{array}$} & \multicolumn{7}{|c|}{ Factors within each scale } \\
\hline & $\begin{array}{l}\text { Relationship } \\
\text { with teacher } \\
\text { (32.7\% vari- } \\
\text { ance) }\end{array}$ & $\begin{array}{l}\text { Enjoyment of } \\
\text { learning } \\
\text { (12.6\% vari- } \\
\text { ance) }\end{array}$ & $\begin{array}{l}\text { Positive } \\
\text { teacher sup- } \\
\text { port } \\
\text { (7.4\% vari- } \\
\text { ance) }\end{array}$ & $\begin{array}{l}\text { Interaction } \\
\text { with teacher } \\
(4.7 \% \text { vari- } \\
\text { ance) }\end{array}$ & $\begin{array}{l}\text { Overall pupil } \\
\text { security } \\
\text { (3.4\% vari- } \\
\text { ance) }\end{array}$ & & \\
\hline Your teacher & $\begin{array}{l}\text { Approachabil- } \\
\text { ity of teacher } \\
\text { ( } 29.1 \% \text { vari- } \\
\text { ance) }\end{array}$ & $\begin{array}{l}\text { Enjoyment of } \\
\text { teaching } \\
18.7 \% \text { vari- } \\
\text { ance) }\end{array}$ & $\begin{array}{l}\text { Teacher ex- } \\
\text { pectations } \\
\text { (3.2\% vari- } \\
\text { ance) }\end{array}$ & $\begin{array}{l}\text { Teacher be- } \\
\text { haviour } \\
\text { (3.1\% vari- } \\
\text { ance) }\end{array}$ & $\begin{array}{l}\text { Use of praise } \\
\text { and reward } \\
2.7 \% \text { variance) }\end{array}$ & $\begin{array}{l}\text { Teacher feed- } \\
\text { back/ assess- } \\
\text { ment } \\
\text { ( } 2.6 \% \text { variance) }\end{array}$ & $\begin{array}{l}\text { Collegiality } \\
\text { (2.5\% vari- } \\
\text { ance) }\end{array}$ \\
\hline $\begin{array}{l}\text { My teacher \& } \\
\text { work }\end{array}$ & $\begin{array}{l}\text { Feelings } \\
\text { about work } \\
(31.3 \% \text { vari- } \\
\text { ance) }\end{array}$ & $\begin{array}{l}\text { Learning in } \\
\text { school } \\
\text { (15.0\% vari- } \\
\text { ance) }\end{array}$ & $\begin{array}{l}\text { Academic } \\
\text { confidence } \\
\text { (8.9\% vari- } \\
\text { ance) }\end{array}$ & $\begin{array}{l}\text { Role behav- } \\
\text { iours of teach- } \\
\text { er } \\
\text { ( } 3.8 \% \text { vari- } \\
\text { ance) }\end{array}$ & $\begin{array}{l}\text { Clarity of } \\
\text { instruction } \\
\text { (1.8\% vari- } \\
\text { ance) }\end{array}$ & & \\
\hline $\begin{array}{l}\text { Other adults } \\
\text { in the class- } \\
\text { room }\end{array}$ & $\begin{array}{l}\text { Supporting } \\
\text { positive be- } \\
\text { haviour } \\
\text { (38.6\% vari- } \\
\text { ance) }\end{array}$ & $\begin{array}{l}\text { Interactions } \\
\text { with other } \\
\text { adults } \\
\text { (17.2\% vari- } \\
\text { ance) }\end{array}$ & & & & & \\
\hline $\begin{array}{l}\text { Pupil partic- } \\
\text { ipation }\end{array}$ & $\begin{array}{l}\text { Participation } \\
\text { in class activ- } \\
\text { ities } \\
\text { ( } 39.5 \% \text { vari- } \\
\text { ance) }\end{array}$ & $\begin{array}{l}\text { Participation } \\
\text { in school ac- } \\
\text { tivities } \\
\text { ( } 21.4 \% \text { vari- } \\
\text { ance) }\end{array}$ & & & & & \\
\hline $\begin{array}{l}\text { You \& other } \\
\text { pupils }\end{array}$ & $\begin{array}{l}\text { Relationship } \\
\text { with other } \\
\text { pupils } \\
\text { (26.8\% vari- } \\
\text { ance) }\end{array}$ & $\begin{array}{l}\text { Interactions } \\
\text { with peers } \\
\text { (15.3\% vari- } \\
\text { ance) }\end{array}$ & $\begin{array}{l}\text { Cooperative } \\
\text { working } \\
\text { (12.4\% vari- } \\
\text { ance) }\end{array}$ & $\begin{array}{l}\text { Positive be- } \\
\text { haviour } \\
\text { ( } 4.1 \% \text { vari- } \\
\text { ance) }\end{array}$ & $\begin{array}{l}\text { Academic } \\
\text { confidence in } \\
\text { pupil } \\
\text { (3.5\% vari- } \\
\text { ance) }\end{array}$ & & \\
\hline $\begin{array}{l}\text { Home-school } \\
\text { relationships }\end{array}$ & $\begin{array}{l}\text { Use of home- } \\
\text { work diary } \\
\text { (34.2\% vari- } \\
\text { ance) }\end{array}$ & $\begin{array}{l}\text { Regular pa- } \\
\text { rental in- } \\
\text { volvement in } \\
\text { pupil home- } \\
\text { work } \\
\text { ( } 24.7 \% \text { vari- } \\
\text { ance) }\end{array}$ & $\begin{array}{l}\text { Parental atti- } \\
\text { tude to pupil } \\
\text { learning } \\
\text { (4.3\% vari- } \\
\text { ance) }\end{array}$ & $\begin{array}{l}\text { Parental en- } \\
\text { gagement in } \\
\text { school activi- } \\
\text { ties } \\
\text { (4.0\% vari- } \\
\text { ance) }\end{array}$ & & & \\
\hline
\end{tabular}

You and other pupils $(\mathrm{KMO}=.765$, Bartlett's Test $p<.001)$

Five factors were identified with eigenvalues exceeding 1 from the YOU AND OTHER PUPILS scale, explaining a total of $62.1 \%$ of the variance (relationship with other pupils, interaction with peers, cooperative working, positive behav- iour, academic confidence in pupil). The results of a reliability test indicated that the overall YOU AND OTHER PUPILS scale showed a moderate level of consistency for both rounds ( $a=0.64 \& 0.71$ respectively). Of the original five factors, one was common across rounds: 
- relationship with other pupils includes items such as I have made many friends in my school, I have got to know other pupils in our school really well, I get along with most other pupils I have met at school $(\mathrm{a}=0.78)$.

Home-school relationships $(\mathrm{KMO}=.706$, Bartlett's Test $p<$ .001)

Four factors with eigenvalues exceeding 1 were identified from the HOME-SCHOOL RELATIONSHIPS scale, explaining a total of $67.2 \%$ of the variance (use of homework diary, regular parental involvement in pupil homework, parental attitude to pupil learning, parental engagement in school activities). The reliability of the overall HOME-SCHOOL RELATIONSHIPS scale in round 1 was moderate $(a=0.72)$. The level of consistency for round 2 was also moderate with the necessary items removed $(\mathrm{a}=0.68)$. One of the four original factors was common across both rounds:

- use of homework diary includes items such as I have a school homework diary which my parent(s)/guardians must see and sign regularly, my teachers check that my parent(s)/guardians have seen my homework diary $(\mathrm{a}=0.80)$.

\subsection{Comparing pupil views}

\subsubsection{Views over time}

Schools were ranked for each of the common factors in terms of pupils' mean scores. This was done for round 1 and round 2 separately, thus making it possible to look across all Year 3 classes at differences in rank positions and derive an indicator of stability or change in pupils' views over the two-year period. The mean scores for each of the common factors were then used to form an aggregated mean score for each school. As the data in Table 3.4 shows, in the Year 3 classes there was relatively little change for five of the nine schools (S2, S3, S4, S5 \& S8) in pupils' views, with the remaining four schools showing changes.

There was an inverse correlation $(r=-.57, n=500, p<$ .001 in round 1 and $r=-.66, n=500, p<.001$ in round 2) between the relative positivity of the pupil views and the FSM group the schools were in. The Year 3 classes with the most positive pupil views across both cohorts were School 3 (ranked $2^{\text {nd }}$ in round $1 \& 3^{\text {rd }}$ in round 2) and School 4 (ranked $1^{\text {st }}$ in both rounds), both of which had a high percentage of pupils eligible for free school meals (FSM 4). The school with the least positive views across both cohorts was School 8 which was an FSM 1 (0-8\% FSM eligibility) school.

Table 3.4. Aggregate Scores for All Common Scales.

\begin{tabular}{llllll}
\hline Year 3 classes & School FSM & Aggregate (R1) & Rank & Aggregate (R2) & Rank \\
School 1 & 3 & 3.44 & 9 & 1.66 & 2 \\
School 2 & 3 & 3.19 & 6 & 1.79 & 6 \\
School 3 & 4 & 2.80 & 2 & 1.67 & 3 \\
School 4 & 4 & 2.73 & 1 & 1.65 & 1 \\
School 5 & 3 & 2.85 & 4 & 1.71 & 4 \\
School 6 & 2 & 2.81 & 3 & 1.91 & 9 \\
School 7 & 1 & 3.23 & 7 & 1.75 & 5 \\
School 8 & 1 & 3.40 & 8 & 1.82 & 7 \\
School $\mathbf{9}$ & 2 & 3.15 & 5 & 1.83 & 8 \\
\hline
\end{tabular}

Two schools showed a shift in the positive responses received from pupils. School 1 improved from $9^{\text {th }}$ (round 1) to $2^{\text {nd }}$ (round 2) and was an FSM 3 school, and School 6 moved from $3^{\text {rd }}$ in round 1 to $9^{\text {th }}$ in round 2 (FSM 2). Therefore, the general trend appears to be that Year 3 pupils in the schools with a higher level of pupil free school meal eligibility were more likely to give positive views on aspects of the interpersonal classroom relationships.

As with the Year 3 classes, Year 6 classes were ranked for each of the common factors in terms of pupils' mean scores separately in round 1 and round 2 . However, as the aggregated data in Table 3.5 show, in the Year 6 classes there was much less stability in pupils' views. In the case of schools that sus- tained pupil views across cohorts, there was a small correlation between the relative positivity of the pupil views and the FSM groups in round $1(r=.15, n=440, p<.001)$ but a more significant correlation in round $2(r=.87, n=440, p<.001)$. The Year 6 pupils with the most positive views across both rounds of data collection attended School 7 (FSM 1) and the school with the least positive views across both cohorts was School 1 (ranked $7^{\text {th }}$ in round $1 \& 9^{\text {th }}$ in round 2 ) which was an FSM 3 school.

Again, two schools showed a shift in the positive responses received from pupils. School 8 , (ranked $9^{\text {th }}$ in round 1 and $2^{\text {nd }}$ in round 2),was an FSM 1 school, and School 5 (ranked $3^{\text {rd }}$ in round 1 and $7^{\text {th }}$ in round 2) was an FSM 3 
school. Unlike the Year 3 pupils, the pattern of Year 6 responses would suggest that it was more likely that pupils in the schools with a lower percentage of free school meal eligibility would report positive views of these relationships.

Table 3.5. Aggregated Scores for All Common Scales.

\begin{tabular}{llllll}
\hline Year 6 classes & School FSM & Aggregate (R1) & Rank & Aggregate (R2) & Rank \\
School 1 & 3 & 2.18 & 7 & 2.29 & 9 \\
School 2 & 3 & 2.08 & 4 & 2.19 & 6 \\
School 3 & 4 & 2.15 & 6 & 2.14 & 5 \\
School 4 & 4 & 2.14 & 5 & 2.23 & 8 \\
School 5 & 3 & 2.06 & 3 & 2.21 & 7 \\
School 6 & 2 & 2.26 & 8 & 2.10 & 4 \\
School 7 & 1 & 1.82 & 1 & 1.60 & 1 \\
School 8 & 1 & 2.30 & 9 & 2.03 & 2 \\
School 9 & 2 & 2.05 & 2 & 2.10 & 4 \\
\hline
\end{tabular}

\subsubsection{Pupil views by year group}

Data from Year 3 and Year 6 pupils did show some similar areas that were important across age groups - for example, relationship with teachers, academic confidence in pupil, enjoyment of learning / learning in school, parental involvement in homework / use of diary, and relationships with other adults.

Table 3.6 indicates that, in round 1, the Year 3 pupils were most positive in relation to the factor relationships with teacher and least positive to the factor parental involvement with homework. Year 6 pupils were most positive in relation to learning in school and least positive to the factors relationship with teacher and relationships with other adults. This may not be surprising as the younger pupils tend to have far more contact with one particular teacher, whereas by the time children reach Year 6, they are quite often taught by teachers with an expertise in a specific subject area such as maths or languages.

Table 3.6. Relationship between Common Factors for Year 3 and Year 6 Pupils (Round 1).

\begin{tabular}{|l|l|l|l|l|}
\hline Common factors across phases & $\begin{array}{l}\text { Mean score } \\
(\text { Yr 3) }\end{array}$ & $\begin{array}{l}\text { Std dev } \\
\text { (Yr 3) }\end{array}$ & $\begin{array}{l}\text { Mean score } \\
\text { (Yr 6) }\end{array}$ & $\begin{array}{l}\text { Std dev } \\
\text { (Yr 6) }\end{array}$ \\
\hline Relationship with teachers & 1.60 & 0.74 & 2.33 & 1.83 \\
\hline Academic confidence in pupil & 2.80 & 1.72 & 2.00 & 1.58 \\
\hline Enjoyment of learning / learning in school & 3.74 & 2.90 & 1.60 & 1.13 \\
\hline Parental involvement in homework / use of diary & 4.10 & 3.05 & 2.17 & 1.44 \\
\hline Relationships with other adults & 3.29 & 2.17 & 2.35 & 1.80 \\
\hline
\end{tabular}

Table 3.7. Relationship between Common Factors for Year 3 and Year 6 Pupils (Round 2).

\begin{tabular}{|l|l|l|l|l|}
\hline Common factors across phases & $\begin{array}{l}\text { Mean score } \\
(\text { Yr 3) }\end{array}$ & $\begin{array}{l}\text { Std dev } \\
\text { (Yr 3) }\end{array}$ & $\begin{array}{l}\text { Mean score } \\
\text { (Yr 6) }\end{array}$ & $\begin{array}{l}\text { Std dev } \\
\text { (Yr 6) }\end{array}$ \\
\hline Relationship with teachers & 1.71 & 0.92 & 2.23 & 1.53 \\
\hline Academic confidence in pupil & 1.66 & 1.06 & 1.94 & 1.10 \\
\hline Enjoyment of learning / learning in school & 1.73 & 1.13 & 1.52 & 0.75 \\
\hline Parental involvement in homework / use of diary & 2.32 & 1.83 & 2.35 & 0.96 \\
\hline Relationships with other adults & 1.74 & 1.13 & 2.25 & 1.05 \\
\hline
\end{tabular}

In round 2 (Table 3.7) Year 3 pupils were most positive in relation to the factor academic confidence in pupil, whereas Year 6 pupils remained most positive about enjoyment of learning / learning in school. The younger pupils remained consistent in relation to their least positive factor parental involvement with homework which was shared by the older 
children.

\subsubsection{Pupil views and school context}

Based on these five common factors across Year groups, the factor scores for individual pupils were used to examine whether the socio-economic context of the schools (as measured by FSM band) affected pupils' attitudes (Tables 3.8 \& 3.9). A two-way between-groups analysis of variance was conducted to explore the attitudes across these common factors with the socio-economic status (using FSM as a proxy) bands. Schools were divided into four groups according to the level of pupil eligibility for free school meals (Group 1: 0-8\%; Group 2: 9-20\%; Group 3: 21-35\%; Group 4: 36\% and above). The data were entered into a 4 (FSM band) $\times 5$ (Factor) mixed measures ANOVA.

Table 3.8. Year 3 Pupils’ Mean Factor Scores (and Standard Deviation) by FSM Band.

\begin{tabular}{|l|l|l|l|l|l|l|l|l|l|l|l|}
\hline & & \multicolumn{2}{|c|}{ F 1 } & \multicolumn{2}{c|}{ F 2 } & \multicolumn{3}{c|}{ F 3 } & \multicolumn{3}{c|}{ F 4 } \\
\hline $\begin{array}{l}\text { FSM } \\
\text { band }\end{array}$ & $\begin{array}{l}\text { No. } \\
\text { schools }\end{array}$ & Mean & Std dev & Mean & Std dev & Mean & Std dev & Mean & $\begin{array}{l}\text { Std } \\
\text { dev }\end{array}$ & Mean & $\begin{array}{l}\text { Std } \\
\text { dev }\end{array}$ \\
\hline 1 & 2 & 1.72 & 0.42 & 1.71 & 0.14 & 1.94 & 0.78 & 2.28 & 0.57 & 2.36 & 0.64 \\
\hline 2 & 2 & 1.70 & 1.13 & 1.66 & 1.06 & 1.83 & 0.99 & 1.88 & 0.14 & 1.67 & 0.21 \\
\hline 3 & 3 & 1.80 & 0.35 & 1.68 & 0.31 & 1.60 & 0.20 & 2.21 & 0.72 & 1.58 & 0.21 \\
\hline 4 & 2 & 1.53 & 1.34 & 1.63 & 1.06 & 1.78 & 0.85 & 3.02 & 0.28 & 1.85 & 1.48 \\
\hline
\end{tabular}

The interaction effect between the five factors and FSM was not statistically significant, $F(3,496)=2.67, p=.47$.
From this data there did not appear to be any strong relationships between the school FSM and Year 3 pupil attitudes.

Table 3.9. Year 6 Pupils' Mean Factor Scores (and Standard Deviation) by FSM Band.

\begin{tabular}{|l|l|l|l|l|l|l|l|l|l|l|l|l|}
\hline & & \multicolumn{2}{|c|}{ F 1 } & \multicolumn{3}{c|}{ F 2 } & \multicolumn{3}{c|}{ F 3 } & \multicolumn{3}{c|}{ F 4 5 } \\
\hline $\begin{array}{l}\text { FSM } \\
\text { band }\end{array}$ & $\begin{array}{l}\text { No. } \\
\text { schools }\end{array}$ & Mean & Std dev & Mean & Std dev & Mean & Std dev & Mean & $\begin{array}{l}\text { Std } \\
\text { dev }\end{array}$ & $\begin{array}{l}\text { Mean } \\
\text { Std } \\
\text { dev }\end{array}$ \\
\hline 1 & 2 & 1.73 & 1.34 & 1.64 & 1.48 & 1.28 & 1.13 & 1.07 & 0.78 & 1.70 & 1.69 \\
\hline 2 & 2 & 2.15 & 1.06 & 1.87 & 1.06 & 1.61 & 0.70 & 2.43 & 1.48 & 2.30 & 1.27 \\
\hline 3 & 3 & 2.34 & 0.57 & 1.99 & 0.44 & 1.57 & 0.97 & 2.16 & 0.35 & 2.25 & 0.50 \\
\hline 4 & 2 & 2.34 & 1.34 & 1.99 & 0.85 & 1.50 & 1.56 & 2.92 & 1.56 & 2.41 & 0.85 \\
\hline
\end{tabular}

However, there seemed to be a statistically significant effect in relation to the Year 6 pupils, $\mathrm{F}(3,496)=17.05, p<$ .001 (Table 3.9) where pupils in FSM 1 schools were more likely to give a positive response.

\subsubsection{Pupil views and teacher career phase}

In a similar manner to that already described for FSM band, results were also analysed according to the career phase of the teachers (Tables 3.10 \& 3.11). A two-way between-groups analysis of variance was conducted to explore the five common factors against the career phase of the teacher. Career phases were divided groups according to level of experience. Three groups were identified for Year 3 (Group 1: 8-15 years; Group 2: 16-23 yrs Group 3: 24+ yrs).

Table 3.10. Year 3 Pupils’ Mean Factor Scores by Career Phase of Teacher.

\begin{tabular}{|l|l|l|l|l|l|l|}
\hline Career phase & No. classes & F1 & F2 & F3 & F4 & F5 \\
\hline 8-15 years & 3 & 1.69 & 1.69 & 1.67 & 2.53 & 1.45 \\
\hline 16-23 years & 3 & 1.88 & 1.71 & 1.92 & 2.68 & 1.90 \\
\hline 24+ years & 3 & 1.55 & 1.59 & 1.59 & 1.76 & 1.88 \\
\hline
\end{tabular}

The data were entered into a 3 (Career phase) x 5 (Factor) mixed measures ANOVA. The interaction effect between the five factors and career phase suggested that, for teachers of
Year 3 pupils, the most experienced in the sample received the most positive views across Factors 1-4. Those teachers in the 16-23 career phase, the data suggested, received the least 
positive views across all five factors $(F(2,497)=7.11, p<\quad .001)$.

Table 3.11. Year 6 Pupils' Mean Factor Scores by Career Phase of Teacher.

\begin{tabular}{|l|l|l|l|l|l|l|}
\hline Career phase & No. classes & F1 & F2 & F3 & F4 & F5 \\
\hline 4-7 years & 3 & 2.20 & 1.93 & 1.49 & 1.80 & 2.02 \\
\hline 8-15 years & 5 & 2.25 & 1.94 & 1.53 & 2.49 & 2.35 \\
\hline 16-23 years & 1 & 2.21 & 2.00 & 1.63 & 3.29 & 2.44 \\
\hline
\end{tabular}

Three groups were identified for Year 6 (Group 1: 4-7 years; Group 2: 8-15 yrs Group 3: 16-23 yrs). The data for Year 6 teachers showed some similarities to the Year 3 data in that those who had been in teaching for between 16 and 23 years received the least positive attitudes for four of the five factors. There seemed to be a statistically significant effect in relation to the Year 6 pupils, $F(2,497)=7.70, p<.001$ (Table 3.10) where teachers in the 4-7 phase were more likely to give a positive response.

\section{Discussion and Conclusion}

The argument put forward in this paper is that the interpersonal relationships encountered by children in primary classrooms can be particularly significant in providing learning environments which contribute to both social and affective outcomes (Birch \& Ladd, 1998; Hamre \& Pianta, 2001; Kington, 2005, Kington, 2012). These environments are closely connected to particular routines, activities, settings and interactions and relate to the quality of the relationships (Hook \& Vass, 2000) and the role of authority in the classroom (Robertson, 1996). Findings presented here also suggest an association between pupils' perceptions of their relationships with a teacher and their feelings of satisfaction with school (Baker, 1999), and social status in the classroom (Skinner \& Belmont, 1993).

A further finding of the research is concerned with the importance of relationships in shaping the quality of pupils' classroom learning experiences and this research supports the findings of such studies as Turner and Meyer (2000) and Osterman (2000) which indicate that the affective and intellectual contexts of classroom learning are an important aspect of children's success at school.

The results from the present study illustrate that there are variations in pupils' perceptions in relation to three possible sources of influence:

i) the year group (between Year 3 and Year 6 pupils) - e.g. relationship with teacher was the most positive factor for Year 3 pupils and the least popular factor for those in Year 6 classes;

ii) the school context (as measured by \% of pupils eligible for free school meals) - e.g. the views of pupils in Year 3 classes did not vary depending on the socio-economic context of the school. However, the views of the Year 6 pupils were more positive in those schools with fewer pupils eligible for free school meals. This was also indicated by the ranking of the factors over time, where Year 6 pupils in FSM 1 schools were more likely to have positive views; and,

iii) the career phase of the class teacher - e.g. those teachers responsible for Year 3 classes were more likely to receive positive views from their pupils if they had been teaching for 24 years or more. For Year 6 teachers, this was true for teachers who had been teaching between 4 and 7 years. Across both year groups, those teachers who were in the 16-23 year phase were more likely to receive less positive pupil views.

Some differences in each of these areas have been identified which indicate that pupils' perceptions of their classroom relationships may be affected by, or be responsive to, these variations. However, it is important to acknowledge the limitations of this study in order to appreciate fully the context within which it was conducted. Primary schools in England, as in most parts of the world, are complex environments, and the restriction of nine case study schools did not give enough flexibility to explore some of the emerging issues regarding the importance of interpersonal relationships in the classroom to their full extent. Given the relatively small sample size of pupils for each year group studied, the results should be treated with caution.

Nonetheless there were indications of significant positive links between pupil perceptions a number of aspects of their classroom relationships. Understanding children's perceptions of interpersonal relationships in classrooms can contribute to discussions around best practice in primary schools. This paper has explored the social and affective outcomes of these relationships from a quantitative perspective and the methodology utilised within this project provided a rich source of data upon which to explore the quantity and frequency of perceptions relating to interactions both with each other and with practitioners. A number of key characteristics have been identified that seem to be common across year groups, school contexts and teacher career phases. Furthermore, the study has also identified other characteristics where there remains variation. These characteristics are, inevitably, only broad descriptors. However, further qualitative data collection (such as interviews with teachers, other staff and 
pupils) could reveal that there is considerable variation in the ways in which these are enacted within different contexts.

\section{References}

Alderman, M.K. (1999). Motivation for Achievement: Possibilities for teaching and learning. Mahwah, NJ: Lawrence Erlbaum Associates.

Baker, J. (1999). Teacher-student interaction in urban at-risk classrooms: Differential behavior, relationship quality, and student satisfaction with school. The Elementary School Journal, 100, 57-70.

Bartlett, M.S. (1954). A note on the multiplying factors for various chi square approximations. Journal of the Royal Statistical Society, 16 (Series B), 296-8.

Birch, S.H., \& Ladd, G.W. (1997). The teacher-child relationship and children's early school adjustment. Journal of School Psychology, 35, 6179.

Birch, S.H., \& Ladd, G.W. (1998). Children's interpersonal behaviors and the teacher-child relationship. Developmental Psychology, 34, 934-946.

Brophy, J. (1998). Motivating Students to Learn. Boston: McGraw Hill.

Connell, J.P. \& Wellborn, J.G. (1991). Competence, Autonomy, and Relatedness: A motivational analysis of self-system processes. The Minnesota Symposia on Child Development: Self processes and development, 23, 43-77.

Day, C., Sammons, P., Stobart, G., Kington, A., \& Gu, Q. (2007). Teachers matter: Connecting lives, work and effectiveness. Maidenhead: Open University Press.

Flutter, J., \& Rudduck, J. (2004). Consulting pupils: What's in it for schools? London: Routledge Falmer.

Hamre, B., \& Pianta, R.C. (2001). Early teacher-child relationships and trajectory of school outcomes through eighth grade. Child Development, 72, 625-638.

Hook, P., \& Vass, A. (2000). Creating winning classrooms. London: David Fulton.

Howes, C., \& Hamilton, C.E. (1993). The changing experience of child care: Changes in teachers and in teacher-child relationships and children's social competence with peers. Early Childhood Research Quarterly, 8, 15-32.

Howes, C., Hamilton, C.E. \& Matheson, C.C. (1994). Children's relationships with peers: Differential associations with aspects of the teacher-child relationship. Child Development, 65, 253-263.

Kaiser, H. (1974). An index of factorial simplicity. Pschometrika, 35, 31-6.

Kington, A. (2005). Qualities, formation and development of teacher-pupil relationships in the primary school. In B. Kozuh, T. Beran, A. Kozlowska \& P. Bayliss (Eds). Measurement and assessment in educational and social research. Exeter-Calgary-Cracow.

Kington, A. (2012). Narratives of variation in teacher-pupil relationships across a career, European Journal of Educational Studies, 4, 2.

Kington, A., Sammons, P., Day, C., \& Regan, E. (2011). Stories and statistics: Describing a mixed method study of effective classroom practice. Journal of Mixed Methods Research, 5, 2, 103-25.

Kutnick, P. \& Kington, A. (2005). Children's Friendships and Learning in School: Cognitive enhancement through social interaction? British Journal of Educational Psychology, 75(4), 521-538.

LaGrange, R.D. (2004). Building strengths in inner city African-American children: The task and promise of schools. In C.S. Clauss-Ehlers \& M.D. Weist (Eds), Community planning to foster resilience in children. New York: Kluwer.

Lynch, M., \& Cicchetti, D. (1992). Maltreated children's reports of relatedness to their teachers. In R.C. Pianta (Ed.), Beyond the parent: The role of other adults in children's lives: New directions for child development (pp. 81-108). San Francisco: Jossey-Bass.

Mitchell-Copeland, J., Denham, S.A., \& DeMulder, E.K. (1997). Q-Sort assessment of child-teacher attachment relationships and social competence in preschool. Early Education and Development, 8, 27-39.

Morgan, B. (2011). Consulting pupils about classroom teaching and learning: Policy, practice and response in one school, Research Papers in Education, 26, 445-467

Oldfather, P., \& Dahl, K. (1994). Toward a Social Constructivist Reconceptualization of Intrinsic Motivation for Literacy Learning. Journal of Reading Behavior, 26, 139-158.

Osterman, K.F. (2000). Students' Need for Belonging in the School Community. Review of Educational Research, 70, 323-367.

Patrick, H. (1997). Social Self-regulation: Exploring the relations between children's social relationships, academic self-regulation, and school performance. Educational Psychologist, 32, 209-220.

Perry, N. (1998). Young Children's Self-regulated Learning and Contexts that Support it. Journal of Educational Psychology, 90, 715-729.

Pianta, R.C. (1999). Enhancing Relationships between Children and Teachers. Washington, DC: American Psychological Association.

Pianta, R.C. (1997). Adult-child Relationship Processes and Early Schooling. Early Education and Development, 8, 11-26.

Pianta, R.C., Steinberg, M., \& Rollins, K. (1995). The first two years of school: Teacher-child relationships and deflections in children's classroom adjustment. Development and Psychopathology, 7, 297312.

Resnick, M.D., Bearman, P.S., Blum, R.W., Bauman, K.E., Harris, K.E., Jones, J., et al. (1997). Protecting Adolescents from Harm: Findings from the national longitudinal study on adolescent health. Journal of the American Medical Association, 278, 823-832.

Robertson, S. (1996). Teachers' work, restructuring and postfordism: Constructing the new 'Professionalism'. In I. Goodson \& A. Hargreaves (Eds) Teachers' Professional Lives. London: Falmer Press.

Ryan, A., Gheen, M.H. \& Midgley, C. (1998). Why do some students avoid asking for help? An examination of the interplay among students' academic efficacy, teachers' social-emotional role, and the classroom goal structure. Journal of Educational Psychology, 90, 528-53 5.

Skinner, E.A., \& Belmont, M. (1993). Motivation in the classroom: Reciprocal effects of teacher behavior and students engagement across the school year. Journal of Educational Psychology, 85, 571-588.

Turner, J.C., \& Meyer, D.K. (2000). Studying and understanding the instructional contexts of classrooms: Using our past to forge our future. Educational Psychologist, 35, 69-85.

Wang, M.C., Haertel, G.D., \& Walberg, H.J. (1997). Fostering educational resilience in inner city schools. In H.J. Walberg, O. Reyes, \& R.P. Weissberg (Eds), Children and youth: interdisciplinary perspectives. Thousand Oaks, CA: Sage Publications.

Wentzel, K.R. (1998). Social relationships and motivation in middle school: The role of parents, teachers, and peers. Journal of Educational Psychology, 90, 202-209.

Wentzel, K.R. (1993). Motivation and achievement in early adolescence: Role of multiple classroom goals. Journal of Early Adolescence, 13, 420.

Werner, E. (2000). Protective factors and individual resilience. In J.P. Shonkoff \& S.J. Meisels (Eds), Handbook of early childhood intervention. New York: Cambridge University Press.

Wigfield, A., Eccles, J.S. \& Rodriguez, D. (1998). The Development of Children's Motivation in School Contexts. In P.D. Pearson \& A. Iran-Nejad (Eds). Review of Research in Education. Washington, DC: AERA. 